\title{
Oxidative stress correlates well with markers of metabolic syndrome in clinically hypothyroid cases: a hospital based study in a remote tribal district
}

\author{
S. Panda ${ }^{1}$, Manoj K. Dash ${ }^{1}$, Pravat K. Thatoi ${ }^{2}$, J. Dandapat ${ }^{3}$, B. Rath ${ }^{4}$ \\ ${ }^{1}$ Pandit Raghunath Murmu Medical College, Baripada, Odisha, India \\ ${ }^{2}$ Sriram Chandra Bhanj Medical College, Cuttack, Odisha, India \\ ${ }^{3}$ Utkal University, Bhubaneswar, Odisha, India \\ ${ }^{4}$ North Odisha University, Baripada, Odisha, India
}

\begin{abstract}
Relevance. Dislipidemia is one of the major manifestation of thyroid disease process due to alteration of metabolic parameters which are also seen in metabolic syndrome. Though oxidative stress has been implicated in both processes, controversial results have been obtained. Objective. To determine the status of lipid peroxidation product (Lpx) in the study group and identify the association of different components of metabolic syndrome. Material and Methods: 102 patients comprising of 60 healthy euthyroid controls and 42 hypothyroid patients served as the study group. Blood samples were collected for fasting blood sugar, renal parameters, lipid profile, tri-iodothyronin $\left(\mathrm{T}_{3}\right)$, thyroxine $\left(\mathrm{T}_{4}\right)$ and thyroid stimulating hormone (TSH). Level of lipid peroxidation in the samples was determined by monitoring the level of thiobarbituric acid like substances (TBARS) like substances. Results. The demographic parameters were significantly altered in hypothyroid patients. Systolic and diastolic blood pressure amongst both the groups was observed to have higher mean value in hypothyroid patients. The fasting blood sugar (FBS), total cholesterol, triacylglycerol, low density lipoprotein (LDL) and high density lipoprotein (HDL) in the hypothyroid was significantly higher than euthyroid control groups. The most frequent alteration in the hypothyroid patients was rise in SBP (95 \%), Hypertriglyceridemia (50 \%) and raised waist circumference (48 \%) and DBP (42 \%). A fourfold rise in Lpx was observed in hypothyroid subjects $(\mathrm{p}<0.001)$. Robust positive association was observed between TSH and Lpx. Multiple linear regressions revealed strongest and statistically significant association between serum serum thyroid stimulating hormone and waist circumference. Conclusion. The hypothyroid patients have significant higher degree of oxidative stress and the components of metabolic syndrome. They are the candidates for preventive health intervention.
\end{abstract}

Key words: Dyslipidemia, metabolic syndrome, lipid peroxidation, TSH

Author contribution. Concept, design and definition of intellectual content: Dr.S. Panda, Dr.J. Dandapat. Literature search and data acquisition: Dr.S. Panda, Dr. M.K. Dash, Dr. P.K. Thatoi. Manuscript preparation and editing: Dr.S. Panda, Dr.B. Rath, Dr. M.K. Dash.

Conflict of interest statement. The authors declare no conflict of interest.

Received 22.09.2020. Accepted 11.11.2020.

(C) Panda S., Dash Manoj K., Thatoi Pravat K., Dandapat J., Rath B., 2021

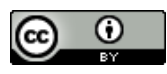

This work is licensed under a Creative Commons Attribution 4.0 International License

https://creativecommons.org/licenses/by/4.0/ 
For citation: Panda S, Dash Manoj K, Thatoi Pravat K, Dandapat J. Rath B. Oxidative stress correlates well with markers of metabolic syndrome in clinically hypothyroid cases: a hospital based case-control study in a remote tribal district. RUDN Journal of Medicine. 2021;25(1):55—65. doi: 10.22363/2313-0245-2021-25-1-55-65

\title{
Корреляция окислительного стресса с маркерами метаболического синдрома в клинических случаях гипотиреоза: исследование на базе больницы в отдаленном племенном районе
}

\author{
С. Панда' ${ }^{1}$ Манодж К. Даш ${ }^{1}$, Прават К. Татой${ }^{2}$, Д. Дандапат ${ }^{3}$ Б. Рат ${ }^{4}$ \\ ${ }^{1}$ Медицинский колледж Пандита Рагхунатха Мурму, г. Барипада, Одиша, Индия \\ ${ }^{2}$ Медицинский колледж Шрирама Чандры Бханджа, г. Каттак, Одиша, Индия \\ ${ }^{3}$ Уткальский университет, г. Бхубанешвар, Одиша, Индия \\ ${ }^{4}$ Университет Норт-Одиша, г. Барипада, Одиша, Индия
}

\begin{abstract}
Аннотация. Актуальность. Дислипидемия является одним из основных проявлений процесса заболевания щитовидной железы из-за изменения метаболических параметров, которые также наблюдаются при метаболическом синдроме. Хотя в оба процесса вовлечен окислительный стресс, результаты различных исследований достаточно противоречивые. Цель: определить статус продукта перекисного окисления липидов (Lpx) в исследуемой группе и выявить взаимосвязь различных компонентов метаболического синдрома. Материалы и методы. Группу исследования составили 102 пациента, из них 60 здоровых пациентов с эутиреоидным контролем и 42 пациента с гипотиреозом. Образцы крови были собраны для определения уровня сахара в крови натощак, параметров почек, липидного профиля, трийодтиронина $\left(\mathrm{T}_{3}\right)$, тироксина $\left(\mathrm{T}_{4}\right)$ и тиреотропного гормона (ТТГ). Уровень перекисного окисления липидов в образцах определяли путем мониторинга уровня веществ, подобных тиобарбитуровой кислоте, подобных веществ и дугим. Результаты. Демографические параметры были значительно изменены у пациентов с гипотиреозом. Было обнаружено, что систолическое и диастолическое артериальное давление в обеих группах имеет более высокое среднее значение у пациентов с гипотиреозом. Уровень сахара в крови натощак, общий холестерин, триацилглицерин, липопротеины низкой плотности и липопротеины высокой плотности в гипотиреозе были значительно выше, чем в контрольных группах с эутиреоидом. Наиболее частым изменением у пациентов с гипотиреозом было повышение САД (95 \%), гипертриглицеридемия (50 \%), увеличение окружности талии (48 \%) и ДАД (42 \%). У пациентов с гипотиреозом наблюдалось четырехкратное увеличение Lpx (p <0,001). Между ТTГ и перекисным окислением липидов наблюдалась стойкая положительная связь. Множественные линейные регрессии выявили сильнейшую и статистически значимую связь между тиреотропным гормоном сыворотки и окружностью талии. Выводы. Пациенты с гипотиреозом имеют значительно более высокую степень окислительного стресса и компонентов метаболического синдрома. Они являются кандидатами на профилактическое медицинское вмешательство.
\end{abstract}

Ключевые слова: дислипидемия, метаболический синдром, перекисное окисление липидов, ТТГ

Вклад авторов. Концепция, дизайн и определение интеллектуального содержания: д-р С. Панда, д-р Дж. Дандапат. Литературный поиск и сбор данных: д-р С. Панда, д-р М.К. Дэш, доктор П. Thatoi. Подготовка и редактирование рукописи: д-р С. Панда, д-р Б. Рат, д-р М.К. Даш.

Заявление о конфликте интересов. Авторы заявляют об отсутствии конфликта интересов.

Поступила 22.09.2020. Принята 11.11.2020.

Для цитирования: Panda S., Dash Manoj K., Thatoi Pravat K., Dandapat J, Rath B. Oxidative stress correlates well with markers of metabolic syndrome in clinically hypothyroid cases: a hospital based case-control study in a remote tribal district // Вестник Российского университета дружбы народов. Серия: Медицина. 2021. Т. 25. № 1. С. 55-65. doi: 10.22363/2313-0245-2021-25-1-55-65 


\section{Introduction}

Thyroid hormones are calorigenic hormones which control several metabolic processes in the body involving the carbohydrate, lipid and proteins. They are involved in the growth and formation of central nervous system, tissue differentiation, reproduction and maintenance of the basal metabolic rate in the various target tissues [1]. Thyroid dysfunction ranks as a second most important endocrine disorder amongst the Indian population. In India, 42 million people suffer from thyroid dysfunction, hypothyroidism being most common. The prevalence of hypothyroidism in India is $11 \%$, compared with only $2 \%$ in the UK and $4 \cdot 6 \%$ in the USA [2].

Hypofunctioning of the thyroid gland occurs in $99.5 \%$ of the cases in Primary hypothyroidism where $0.5 \%$ of the cases is due to pituitary and hypothalamic dysfunction and termed as secondary hypothyroidism. The levels of thyroid hormones are low and TSH levels are higher than normal in primary hypothyroidism. In secondary hypothyroidism, TSH level is below normal leading to the deficiency of the thyroid hormones. On the other hand, subclinical hypothyroidism is an early manifestation of the disease process, where serum TSH levels are elevated with serum thyroid hormones remaining within the reference range.

Dislipidemia is one of the major manifestations of hypothyroidism resulting from accumulation of Cholesterol, LDL and apolipoprotein B [3]. Many factors are responsible for the significant hypercholesterolemia - mostly due to the predominant role of thyroid hormones in upregulating the LDL receptors as cited in previous studies [4, 5]. The hypometabolic state in hypothyroidism has been shown to be associated with oxidative stress due to imbalance between generation and clearance of reactive oxygen species[6]. However, this association of oxidative status with the hypothyroid state is controversial and various conflicting results have been obtained. Some studies state that there is metabolic depression in hypothyroidism which results in decreased oxidant production where as others have opined that lipid peroxidation is high in hypothyroid patients due to underlying dyslipidemia [7, 8].

Thyroid dysfunction results in alteration of metabolic parameters such as lipids, glucose and blood pressure which are also seen in metabolic syndrome [9].The major components of metabolic syndrome include hyperglycemia, dyslipidemia, hypertension - result in cardiovascular complications which is one of most common causes of death worldwide. Oxidative stress has also been implicated in metabolic syndrome but various controversial results have been obtained justifying the cause effect relationship. Coexistence of metabolic syndrome with hypothyroidism may aggravate the cardiovascular and metabolic risk factors [10]. The present study was designed and carried out to explore the relationship between oxidative stress marker like serum Lpx and clinical and biochemical markers of metabolic syndrome in clinically diagnosed hypothyroid cases.

\section{Materials and methods Study design}

This study was conceptualized as a prospective hospital-based study with cross sectional design. The prospective study subjects were the adult patients of both sexes who presented to the Internal medicine OPD of the medical college and were clinically diagnosed to be cases of hypothyroidism. Of these clinically diagnosed cases of hypothyroidism those patients who self-reported to the Central laboratory of Tertiary Care Hospital, Baripada, India for the various investigations in a fasting state were the intended study subjects. The study subjects were then selected on the principle of consenting, convenient and consecutive sampling. It is desirable to note here that the work was done in a remote tribal district called Mayurbhanj, located in the northern part of the state of Odisha, in India. The district is an underdeveloped and backward tribal district with a predominantly tribal population (58.7\% as per 2011 census). Likewise this study was conducted with the limited resources available in the biochemistry department of a newly established medical college (started in 2017) which was established in this remote 
area with the joint efforts of the central and state governments. All research participants submitted for data processing.

\section{Inclusion and exclusion criteria}

The present analysis was restricted to the study subjects who could be enrolled between August 2019 and January 2020. The enrolment could not proceed beyond the last week of January 2020 as there was significant social and administrative turmoil related to the outbreak of COVID-19 resulting in the administrative shifting of laboratory, clinical staff between different units of the hospital as a part of preparedness for the impending outbreak. The cue for enrolment in this study was a clinical diagnosis of hypothyroidism by a physician in the Medicine OPD and those who self-reported to the central lab for diagnostic tests but were not yet on any medication for hypothyroid state. In addition all subjects who self-reported a history of the following medical conditions and/ or were receiving medications for the same were excluded from the study viz.

a) Any pre-existing form of thyroid dysfunction (other than hypothyroid);

b) Diabetes Mellitus (type 1 or 2 or GDM);

c) Essential hypertension;

d) Pregnant and lactating mothers;

e) Malignancy;

f) H/o recent surgery (minor or major) within the last 8 weeks (prior to date of enrollment);

g) Chronic neurological, cardiovascular, respiratory, renal or hepatic disorders and any such acute illness in the last 8 weeks;

h) Psychiatric illness or medication for there on (acute or chronic);

i) Smokers, alcoholics and persons with h/o substance abuse;

j) Any chronic debilitating condition where the ADL (activities of daily living) of the person was severely restricted.

The exclusion criteria were needed to be stringent (if not exhaustive) because oxidative stress markers are known to be very sensitive. Therefore the exploration of their relationship with a specific clinical condition like hypothyroidism necessitated the exclusion of all other possible conditions which could easily be a cause of bias while interpreting the results.

All the willing and eligible study subjects were explained the purpose and design of the study and consent was sought from each of them before enrolment in the study. A total of 102 patients, aged between 21 and 70 years of both sexes were included in the study after applying the inclusion and exclusion criteria of the study. Ethical aspects of the study design and protocol had been submitted for approval to the institutional authorities and the ethical committee of the medical college prior to onset of the study.

\section{Laboratory protocol}

Blood samples (venous blood) were collected by standard venepuncture methods in the laboratory by the laboratory technicians who had already been sensitized and briefed about the study. All the enrolled study subjects had self-reported to the central lab after overnight fasting as they had already been briefed for the same by the treating physician in the OPD. All the socio-demographic, clinical and anthropometric parameters of the study subjects were also assessed from in the lab itself on their first visit (after collection of their blood samples) by tutors of the department of biochemistry who were on duty in the central lab.

Biochemical parameters like fasting plasma sugar - FPG, glycosylated hemoglobin - Hba1c, serum urea, serum creatinine, serum lipid profile (Total cholesterol - TC, Triacylglycerol — TG, Low density lipoprotein - LDL and High density lipoprotein - HDL) were assessed in XL 360 automated analyzer and serum $\mathrm{T}_{3}, \mathrm{~T}_{4}$ and thyroid stimulating hormone - TSH were assayed in the Access II Beckmann Coulter immunoassay system using the manufacturer recommended and designated kits in the central lab of the medical college.

The serum lipid peroxidation product-Lpx was used as an oxidative stress marker in this study was determined using the method recommended 
by Okhawa et al (1979). This involves monitoring the level of thiobarbituric acid like substances (TBARS) where the final product has an absorption maximum at $532 \mathrm{~nm}$. To prevent auto-oxidation of the samples butylated hydroxyl toluene was used in the assay mixture. The instruments required for the assessment of this parameter were (especially cold nano-centrifuge) malfunctioned one month into the study hence the lead author who is also a Phd scholar and had access to the lab of the biotechnology department at Utkal university got the samples processed for serum Lpx in batches at that lab taking all due precautions for transport and handling of the samples.

The blood pressure (systolic blood pressure SBP and diastolic blood pressure - DBP) of the study subjects was measured using the digital model of OMRON make using an arm cuff in millimeters of mercury (mmHg). The anthropometric measurements were made using standard anthropometric equipment: Digital weighing scale of CAS make for recording weight (Wt) in kilograms (kg), Stadiometer of Falcon make for recording height $(\mathrm{Ht})$ in centimeters (cm) and SECA 201 for measuring waist circumference (WC) in centimeters (cm). The standard protocol for clinical anthropometry prescribed by the World Health Organisation (WHO) was followed while making the anthropometric assessments of the study subjects.

\section{Metabolic syndrome}

The exact definition of metabolic syndrome has been a source of controversy for researchers with multiple professional bodies (like ATP III panel, WHO, International Diabetic Federation, etc) having varying criteria for identifying the cases of metabolic syndrome. At last, in 2009 the various professional bodies had reached a consensus to define a case of metabolic syndrome based on a common set of parameters and cut off values. Thus a person was said to have metabolic syndrome if he/ she fulfilled any three of the six criteria i.e. elevated waist circumference (population and country specific definitions - for India $>80 \mathrm{~cm}$ for females and $>$ $90 \mathrm{~cm}$ for males) or elevated triglycerides ( $>150$ mg / dL) or reduced HDL cholesterol ( $<40 \mathrm{mg} / \mathrm{dL}$ for males and $<50 \mathrm{mg}$ / dL for females) or elevated systolic blood pressure ( $>130 \mathrm{mmHg}$ ) or elevated diastolic blood pressure $(>85 \mathrm{mmHg}$ ) or elevated fasting glucose (>100 mg/ dL) [11, 12]. The present study used the above said consensus statement as guiding values to evaluate patients for presence of markers of metabolic syndrome.

\section{Statistical analysis}

Quantitative data were expressed as mean and standard deviation. Categorical data were expressed as counts. Chi-square test was used to compare the categorical variables and the Student't' test was used to compare continuous variables. The linear relationship between the quantitative variables was evaluated by computing the Pearson's correlation coefficients. The independent relationship between Lpx and other study parameters was analyzed by multiple linear regression. All the statistical analysis was done using SPSS version 20. (SPSS Inc., Chicago, Ill., USA). Probability less than 0.05 was considered as statistically significant for this study.

\section{Results and discussion}

The study was conducted with a total of 102 individuals consisting of 34 males and 68 females, meeting the inclusion and exclusion criteria. The distribution of males and females in the two study groups was similar $(p=0.286)$. The age, ethnicity and residential characteristics of the study subjects distributed into the two groups: euthyroid $(n=60)$ and hypothyroid ( $n=42)$ showed no statistically significant differences. However the markers of metabolic syndrome were all significantly different in both the group. The mean levels of waist circumference (WC), systolic blood pressure (SBP), diastolic blood pressure (DBP), triglyceride (tag), low density lipoprotein (LDL), high density lipoprotein (HDL), fasting plasma glucose (FPG), glycosylated hemoglobin (Hba1c), thyroid stimulating hormone (TSH) and the serum lipid peroxidase (Lpx) were all higher in the hypothyroid group than the euthyroid study subjects (Table 1 ). 
Panda S. et al. Вестник РУДН. Серия: Медицина. 2021. Т. 25. № 1. С. 55-65

Comparison of socio-demographic and serum markers of the study subjects in the two groups

Table 1

Таблица 1

Сравнение социально-демографических параметров и маркеров сыворотки крови в двух группах пациентов

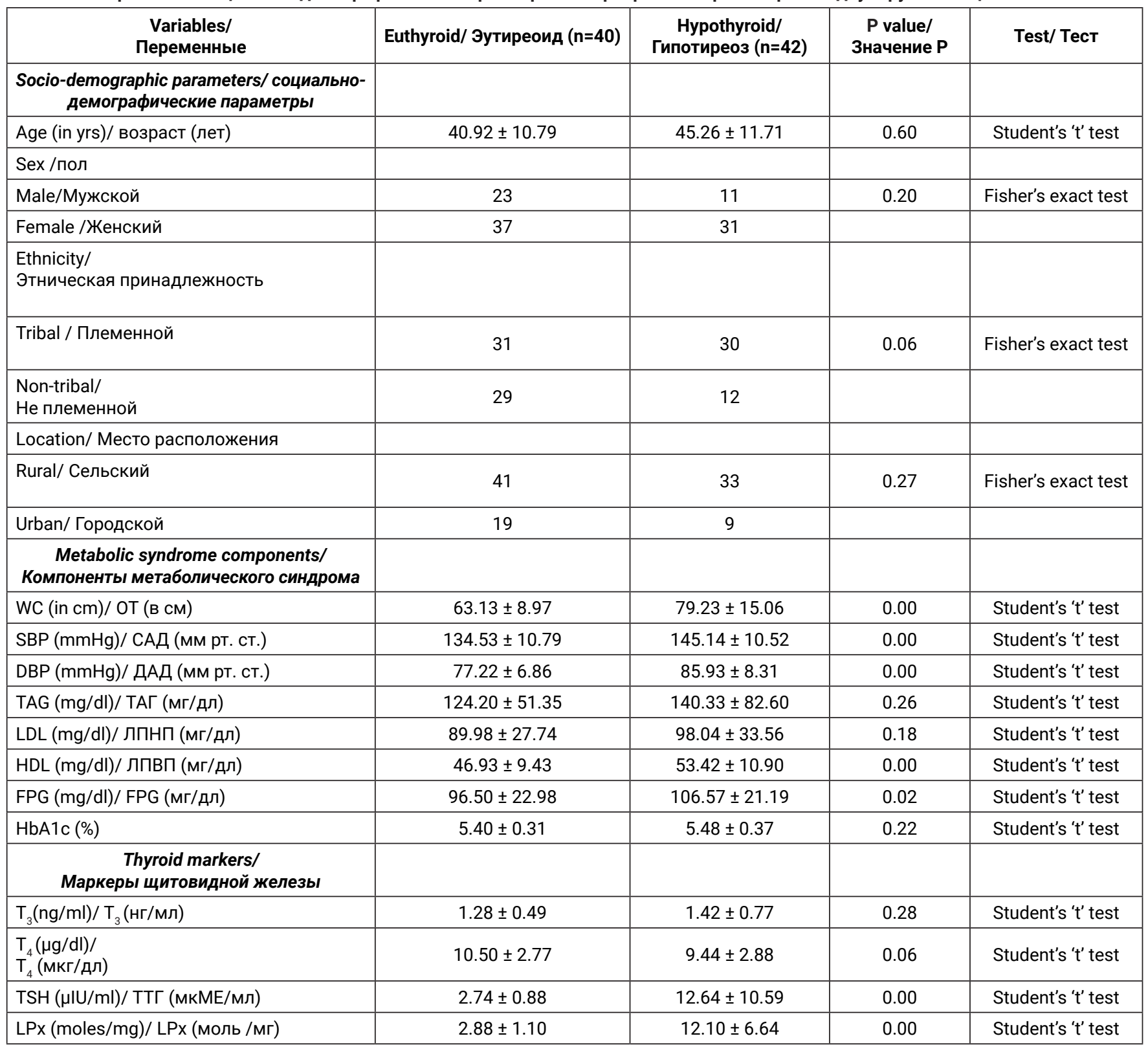

Note: WC - Waist circumference, SBP - Systolic blood pressure, DBP - Diastolic blood pressure, TAG -Triglyceride, LDL - Low density lipoprotein, FPG -Fasting plasma glucose, HDL - High density lipoprotein, HbA1c - Glycosylated hemoglobin, $T_{3}-\mathrm{Tri}$ iodothyronine, $\mathrm{T}_{4}$ - Thyroxine, TSH - thyroid stimulating hormone, Lpx - Hormone Lipid peroxidation product.

Примечание: ОТ - окружность талии, САД - систолическое артериальное давление, ДАД - диастолическое артериальное давление, ТАГ-триглицерид, ЛПНП - липопротеины низкой плотности, FPG - уровень глюкозы плазмы крови натощак, ЛПВП - липопротеины высокой плотности, НbA1с - гликозилированный гемоглобин, Тз-трийодтиронин, $\mathrm{T}_{4}$ - тироксин, ТТГ - тиреотропный гормон, Lpx - продукт перекисного окисления липидов гормона. 
The linear association between the various quantitative study parameters was assessed by computing the Pearsons's correlation coefficient ' $r$ '. The ' $r$ ' values between the serum oxidative stress marker — Lpx and the other study parameters are shown in Table 2. The parameters - thyroid stimulating hormone (TSH) and waist circumference (WC) showed robust ( $\mathrm{r}>0.5$ ) and statistically significant correlation whereas systolic blood pressure (SBP), diastolic blood pressure (DBP), high density lipoprotein (HDL) and thyroid hormone $\left(\mathrm{T}_{4}\right)$ showed modest $(\mathrm{r}<0.5)$ but statistically significant correlation.

In order to ascertain the independent relationships between Lpx and the important markers of metabolic syndrome assessed in this study, statistical modeling was done using multiple linear regression. Thus Lpx was regressed on thyroid stimulating hormone (TSH), waist circumference (WC). The other study parameters were not included in the regression model because either they failed to show a robust and statistically significant linear correlation with Lpx or successive iterations of the regression model in a step wise manner failed to show any valid increase in the adjusted r-square of the model. Thus the final model included lpx regressed on TSH and WC. The model was statistically significant. The standardized beta coefficients were used to compare the model parameters since the natural units of measurement were different for each parameter. After adjusting for the confounders, the result of multiple linear regression of the final model is depicted in Table 3. The results thus affirm the relationship between the serum oxidative stress marker — Lpx and serum thyroid stimulating hormone (TSH) and waist circumference (WC).

The present study comprised of 102 subjects attending the medicine OPD, suspected of having thyroid dysfunction. Such patients were screened based on the TSH level into hypothyroid patients and euthyroid healthy control. There were 60 healthy controls and 42 hypothyroid patients.

Dyslipidemia and atherosclerosis are most common manifestations of the hypothyroid state. In this study also, the hypothyroid patients had dyslipidemia which is in line with the work conducted by other authors [13-15]. Thyroid hormone facilitates expression of LDL receptor, thus the hypothyroid state causing downregulation of LDL receptors which impairs the clearance of cholesterol from the peripheral tissues [16,
17].Raised TG level was also seen in the hypothyroid subjects may be due to the decreased activity of the lipoprotein lipase present in the endothelial lining.

Oxidized low density lipoproteins act as risk factor for atherosclerosis. A study conducted by Diekman et al [18] showed that LDL from hypothyroid patients is more vulnerable for oxidation, indicating Oxidative stress. Olinescu et al [19] showed an increase in lipid peroxidation product (Lpx) level in obese hypothyroid women. Oxidative stress has been attributed for the development and progression of various pathophysiological conditions such as endothelial dysfunction, hypertension and atherosclerotic cardiovascular disease [20].The present study reveals fourfold increase in the oxidative stress parameter Lpx in the hypothyroid points which is significant statistically. The increased generation of reactive oxygen species in the hypothyroid patients is probably attributed to the significant dyslipidemia observed amongst the cases. Similar results were also documented in studies conducted by other authors [21-23]. Oxidative stress in the hypothyroid patients is due to the hypo metabolic state seen due to imbalance between the generation and clearance of ROS.

Most patients with hypothyroidism are prone for cardiovascular disease owing to significant dyslipidemia seen in such cases. Subjects with hypothyroidism are also associated with one or more components of metabolic syndrome. The traits of metabolic syndrome are well documented cardiovascular risk factors that co-occur in an individual with hypothyroidism [24, 25].

Though insulin resistance plays a key role in metabolic syndrome, several studies have concluded that increased oxidative stress and chronic low level inflammation may have important roles in metabolic syndrome related manifestations [26-28]. Existing studies reveal that oxidative stress could be an early event in the pathology of these chronic diseases rather than merely a consequence [29].In our study, we have found the association of the hypothyroid state with the different components of metabolic syndrome such as raised waist circumference, systolic and diastolic blood pressure and hypercholesterolemia. Rest of the components of metabolic syndrome was more frequently observed in the hypothyroid subgroup than the euthyroid group. The most important variation was the rise in Lpx, an indicator of oxidative stress in hypothyroid subgroup (Table 2). 
Panda S. et al. Вестник РУДН. Серия: Медицина. 2021. Т. 25. № 1. С. 55-65

Matrix of linear correlation coefficients of various study parameters vs. lipid peroxidase (Lpx)

Матрица коэффициентов линейной корреляции различных параметров исследования относительно липидпероксидазы (Lpx)

\begin{tabular}{|c|c|c|c|c|c|c|c|c|c|c|c|c|c|}
\hline $\begin{array}{c}\text { Variables/ } \\
\text { Пере- } \\
\text { менные }\end{array}$ & $\begin{array}{c}\text { Age } \\
\text { (yrs)/ } \\
\text { Возраст } \\
\text { (лет) }\end{array}$ & $\begin{array}{c}\text { WC } \\
(\mathrm{cm}) / \\
\text { OT (cM) }\end{array}$ & $\begin{array}{c}\text { SBP } \\
(\mathrm{mmHg}) / \\
\text { САД } \\
\text { (мм рт. } \\
\text { ст.) }\end{array}$ & \begin{tabular}{|c|} 
DВР \\
(mmHg)/ \\
ДАД \\
(мм рт. \\
ст.)
\end{tabular} & $\begin{array}{c}\text { TAG } \\
\text { (mg/dl)/ } \\
\text { TAГ (MГ/ } \\
\text { АЛ })\end{array}$ & $\begin{array}{c}\mathrm{LDL} \\
(\mathrm{mg} / \mathrm{dl}) / \\
\text { ЛПНП } \\
\text { (Мг/дл) }\end{array}$ & $\begin{array}{c}\mathrm{HDL} \\
(\mathrm{mg} / \mathrm{dl}) / \\
\text { ЛПВП } \\
\text { (мг/Aл) }\end{array}$ & $\begin{array}{c}\text { FPG (mg/ } \\
\text { dl)/ FPG } \\
\text { (Мг/дл) }\end{array}$ & $\begin{array}{c}\text { HbA1C } \\
\text { (\%) }\end{array}$ & $\begin{array}{c}\mathrm{T}_{3} \\
(\mathrm{ng} / \mathrm{ml}) / \\
\mathrm{T}_{3}(\mathrm{Hr} / \\
\text { мл) }\end{array}$ & $\begin{array}{c}\mathrm{T}_{4} \\
(\mu \mathrm{g} / \mathrm{dl}) / \\
\mathrm{T}_{4}(\mathrm{MKr} / \\
\text { дл) }\end{array}$ & $\begin{array}{c}\text { TSH } \\
(\mu \mathrm{UU} / \mathrm{ml}) / \\
\text { TTГ } \\
\text { (мкME / } \\
\text { мл) }\end{array}$ & $\begin{array}{c}\text { Lpx } \\
\text { (moles/ } \\
\text { mg)/ Lpx } \\
\text { (моль/мг) }\end{array}$ \\
\hline $\begin{array}{c}\text { Pearson's } \\
\text { ' } r \text { ' }\end{array}$ & 0.072 & 0.549 & 0.357 & 0.217 & 0.049 & 0.190 & 0.236 & 0.113 & -0.013 & -0.071 & -0.275 & 0.880 & 1 \\
\hline$p$ value & 0.47 & 0.00 ** & 0.00 ** & 0.02 * & 0.62 & 0.05 & 0.01 * & 0.260 & 0.898 & 0.47 & 0.00 ** & 0.00 ** & - \\
\hline
\end{tabular}

$\star(p<0.05) * \star(p<0.001)$

Note: WC - Waist circumference, SBP - Systolic blood pressure, DBP - Diastolic blood pressure, TAG -Triglyceride, LDL - Low density lipoprotein, FPG -Fasting plasma glucose, HDL - High density lipoprotein, HbA1c - Glycosylated hemoglobin, $T_{3}$ - Tri iodothyronine, $\mathrm{T}_{4}$ - Thyroxine, TSH - thyroid stimulating hormone, Lpx - Hormone Lipid peroxidation product.

Примечание: ОТ - окружность талии, САД - систолическое артериальное давление, ДАД - диастолическое артериальное давление, ТАГ-триглицерид, ЛПНП - липопротеины низкой плотности, FPG - уровень глюкозы плазмы крови натощак, ЛПВП - липопротеины высокой плотности, НbА1с - гликозилированный гемоглобин, Тз-трийодтиронин, $\mathrm{T}_{4}$ - тироксин, ТТГ - тиреотропный гормон, Lpx - продукт перекисного окисления липидов гормона.

Significant positive association has been observed between TSH and Lpx in this study. CRP though positively associated with TSH does not reveal any statistical significance. Various other studies [30, 31] have reported that hypothyroidism associated oxidative stress is the consequence of both increased production of free radicals and reduced capacity of the anti-oxidative defense. In our study, $\mathrm{T}_{4}$ but not $\mathrm{T}_{3}$ revealed a significant negative association with oxidative stress. Altered thyroid hormone levels are one of the physiological modulators of cellular oxidative stress due to their known effects on mitochondrial respiration [21].

A significant correlation between Lpx and waist circumference, systolic and diastolic blood pressure has been observed in this study (Table 3).

Standardized regression coefficients of multiple linear regression of Lpx

Table 3 Коэффициенты стандартизованной регрессии множественной линейной регрессии LpX

\begin{tabular}{|c|c|c|c|}
\hline \multicolumn{3}{|c|}{ Model $1^{\wedge} /$ Модель $1^{\wedge}$} & \multirow{2}{*}{$\frac{P \text { value/Значение } P}{0.00}$} \\
\hline R square/R квадрат & Coefficient & 0.8026 & \\
\hline Model parameter/ Параметр модели & $\begin{array}{l}\text { Coefficient/ } \\
\text { Коэффициент }\end{array}$ & $\begin{array}{c}\text { Standardized beta coefficient/ } \\
\text { Стандартизированный бета-коэффициент }\end{array}$ & $P$ value \\
\hline WC (incm)/OT (в см) & 0.083 & 0.188 & 0.00 ** \\
\hline Constant/ Постоянная & -3.18 & -3.18 & $0.03 *$ \\
\hline
\end{tabular}

Note: ${ }^{\wedge}$ Lpx is the dependant variable and TSH and WC are the independent variables, * $(p<0.05), \star \star(p<0.001)$, TSH- Thyroid stimulating Hormone, WC- Waist circumference.

Примечание: ^ Lpx - зависимая переменная, а ТTГ и WC - независимые переменные, *(p<0,05), **(p<0,001), TSHтиреотропный гормон, ОТ - окружность талии. 


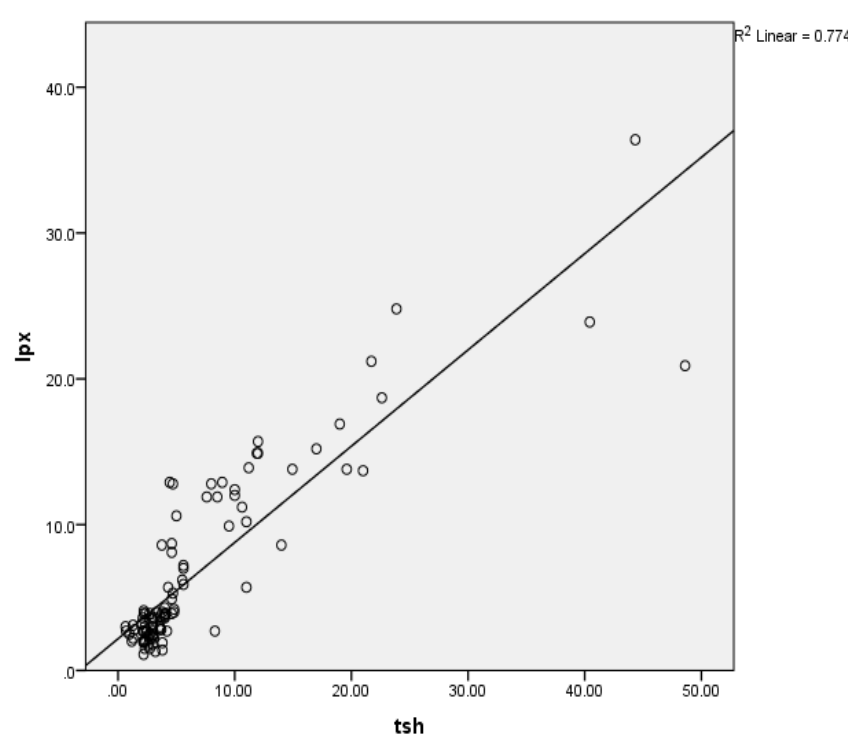

Fig. 1. The linear relationship between data of variable $L p x$ in $Y$ axis and TSH in $\mathrm{X}$ axis in the form of a scatter plot.

Рис. 1. Линейная зависимость между данными переменной LpX по оси Y и TSH по оси X в виде диаграммы разброса.

Oxidative stress ensues, when the storage capacity of the adipocytes is exceeded, resulting in its hypertrophy. Higher release of pro inflammatory cytokines such as IL-1, IL-6 and TNF- $\alpha$ generates a low grade inflammation which begins in the adipose tissue and eventually reaches the circulation and other organs [32, 33].

The systolic and diastolic blood pressure are positively correlated with biomarkers of oxidative stress and negatively correlated with the levels of antioxidants in the results obtained from several studies [34-36]. This fact is attributed to endothelial dysfunction caused by oxidative stress and inflammation, producing imbalance of vasoconstrictor and vasodilator products.

\section{Conclusion}

The hypothyroid patients have significant higher degree of oxidative stress compared to euthyroid patients. Since oxidative stress is associated with adverse cardiovascular events due to underlying metabolic syndrome, they are the candidates for preventive health intervention. Effective screening of the hypothyroid patients for obesity, hypertension, hyperglycemia and dyslipidemia will identify the metabolic syndrome in such patients. Early intervention in the form of lifestyle modification, behavioral therapy, diet education and nutritional therapy should be implemented to prevent the future cardiovascular risk.

\section{Study limitations}

1. The present study was executed as a pilot study in a resource constrained set up (in a newly established medical college hospital's central laboratory). The assessment of biochemical parameters was restricted to the range and type of instruments available in the central lab of the biochemistry department. The assessment of free T3 and free T4 and the assessment of other biochemical parameters like apolipoprotein-B levels could have provided more strength to the study objectives and analysis but the same are not currently available for assay in the central lab.

2. The ethnicity of the study subjects in our study was predominantly tribal (more than $75 \%$ of the participating study subjects were ethnically tribal and more than $50 \%$ had legal status as Scheduled Tribes as per the official Scheduled Tribe list of the government of Odisha). However because of sensitivity of the issue and the hospital being a public funded health facility, exclusion of nontribal patients in the central lab where they were consecutively self-reporting was not legally possible.

3. The exclusion criteria were affected by selfreporting as the design of the study was as such. Home visits or validation of the previous medical records to independently verify the veracity of the exclusion criteria in each enrolled study subject was not logistically feasible within the limitation of the resources available to the authors.

4. The study, in as much the sample size was effectively limited by the un-anticipated turn of events following the outbreak of the COVID-19 pandemic.

\section{References/Библиографический список}

1. Pasupathi PP, Latha R. Free Radical Activity and Antioxidant Defense Mechanisms in Patients with Hypothyroidism. Thyroid Sci 2008;3(12):CLS1-6.

2. Nivedita N, Bobby Z, Abdoul H. Association of lipid risk factors with lipid peroidation in hypothyroidism. Clin Chem Lab Med 2008;46(5):674-679.

3. Santi A, Duarte MM, deMenezes CC, Loro VL. Association of Lipids with Oxidative Stress Biomarkers in Subclinical 
Hypothyroidism. Int J Endocrinol . 2012:Article ID 856359, doi:10.1155/2012/856359.

4. Turhan S, Sezer S, Erden G. et al. Plasma homocysteine concentrations and serum lipid profile as atherosclerotic risk factors in subclinical hypothyroidism. Ann Saudi Med. 2008;28(2):96-101.

5. Hueston WJ. and Pearson WS. Subclinical hypothyroidism and the risk of hypercholesterolemia. Annals Family Med. 2004;2(4):351-355.

6. Baskol G, Atmaca H, Tanriverdi F, Baskol M, Kocer M, Bayram F. Oxidative stress and enzymatic antioxidant status in patients with hypothyroidism before and after treatment. Experi Clin Endocrinol Diab. 2007;115(8):522-526.

7. Torun AN, Kulaksizoglu S, Kulaksizoglu M, Pamuk BO, Isbilen E, Tutuncu NB. Serum total antioxidant status and lipid peroxidation marker malondialdehyde levels in overt and subclinical hypothyroidism. Clin Endocrinol. 2009;70(3):469-474.

8. Messarah M, Boumendjel A, Chouabia A. et al. Influence of thyroid dysfunction on liver lipid peroxidation and antioxidant status in experimental rats. Experi Toxicol Pathol. 2010;62(3):301-310.

9. Rizos CV, Elisaf MS, Liberopoulos EN. Effects of thyroid dysfunction on lipid profile. Open Cardiovasc Med J. 2011;5:76-84.

10. Wolffenbuttel BHR, Wouters HJCM, Slagter SN. et al. Thyroid function and metabolic syndrome in the population based Life Lines cohort study. BMC Endocrine Disorders. 2017;17(1), p. 65.

11. World Health Organization. Obesity: preventing and managing the global epidemic. Report of a WHO Consultation on Obesity. Geneva: The Organization (WHO Technical Report Series, No. 894), 2000.

12. Expert Panel on Detection, Evaluation, and Treatment of High Blood Cholesterol In Adults 2001 Executive Summary of The Third Report of The National Cholesterol Education Program (NCEP) Expert Panel on Detection, Evaluation, And Treatment of High Blood Cholesterol In Adults (Adult Treatment Panel III). JAMA. 285:2486-2497.

13. Efstathiadou Z, Bitsis S, Milionis HJ. et al. Lipid profile in subclinical hypothyroidism: is L-thyroxine substitution beneficial? European J Endocrinol . 2001;145(6):705-710.

14. Yildirimkaya M, Zata MO, Yilmaz K, Kilinc C, G“undǒgan MA, Kutluay T. Lipoprotein (a) concentration in subclinical hypothyroidism before and after levo-thyroxine therapy. Endocrine J. 1996;43(6):731-736.

15. Miura S, Iitaka M, Yoshimura H. et al. Disturbed lipid metabolism in patients with subclinical hypothyroidism: effect of L-thyroxine therapy. Internal Med. 1994;33(7):413-417.

16. Turhan S, Sezer S, Erden G. et al. Plasma homocysteine concentrations and serum lipid profile as atherosclerotic risk factors in subclinical hypothyroidism. Annals Saudi Med. 2008;28(2): 96-101.

17. Lu L, Wang B, Shan Z. et al. The correlation between thyrotropin and dyslipidemia in a population-based study. J Korean Med Sci. 2011;26(2):243-249.

18. Diekman T, Demacker PN, Kastelein JJ, Stalenhoef AF, Wiersinga WM. Increased oxidizability of low density lipoproteins in hypothyroidism. J Clin Endocrinol Metab. 1998;83:1752-5.

19. Olinescu R, Radaceanu V, Nita S, Lupeanu E. Age dependent variations of the plasma peroxides and total antioxidants inwomen with obesity and hypothyroidism. Rom J Intern Med. 1992;30:285-90.

20. Aizawa K, Shoemaker JK, Overend TJ, Petrella RJ. Metabolic syndrome, endothelial function and lifestyle modification. Diab Vasc Dis Res. 2009;6:181-189.
21. Bhimte B, Agrawal BK, Sharma VK, Chauhan SS. Oxidative stress status in hypothyroid patients. Biomed Res. 2012;23(2):286-288.

22. Messarah M, Boumendjel A, Chouabia A. et al. Influence of thyroid dysfunction on liver lipid peroxidation and antioxidant status in experimental rats. Experi Toxicol Pathol. 2010;62(3):301-310.

23. Nanda N, Bobby Z, Hamide A. Association of thyroid stimulating hormone and coronary lipid risk factors with lipid peroxidation in hypothyroidism. Clinical Chem Lab Med. 2008;46(5):674-679.

24. Solanki A, Bansal S, Jindal S. et al. Relationship of serum thyroid stimulating hormone with body mass index in healthy adults. Indian J Endocrinol Metab. 2013; 17(Suppl1):S167.

25. Xu B, Yang H, Wang Z. et al. Elevated thyroid stimulating hormone levels are associated with metabolic syndrome in a Chinese community-based population of euthyroid people aged 40 years and older. J Biomed Res. 2016;30:476.

26. Ceriello A, Motz E. Is oxidative stress the pathogenic mechanism underlying insulin resistance, diabetes, and cardiovascular disease? The common soil hypothesis revisited. Arterioscler Thromb Vasc Biol. 2004;24:816-823.

27. Van Guilder G.P., Hoetzer G.L., Greiner J.J., Stauffer B.L., Desouza CA. Influence of metabolic syndrome on biomarkers of oxidative stress and inflammation in obese adults. Obesity (Silver Spring). 2006;14:2127-2131.

28. Skalicky J, Muzakova V, Kandar R, Meloun M, Rousar T, Palic$\mathrm{ka}$ V. Evaluation of oxidative stress and inflammation in obese adults with metabolic syndrome. Clin Chem Lab Med. 2008; 46: 499-505.

29. Sa'́nchez-Rodríguez M, Martı́nez-Cruz M, Correa-Muñoz E, Mendoza-Núñez V. Relationship between metabolic syndrome components and oxidative stress in elderly community-dwelling Mexicans. Ann Nutr Metab. 2010;56: 302-307.

30. Yilmaz S, Ozan S, Benzer F, Canatan H. Oxidative damage and antioxidant enzyme activities in experimental hypothyroidism. Cell Biochem Funct. 2003;21(4):325-330.

31. Carmeli E, Bachar A, Barchad S, Morad M, Merrick J. Antioxidant status in the serum of persons with intellectual disability and hypothyroidism: A pilot study. Res Development Disab. 2008;29:431-438.

32. Cotillard A, Poitou C, Torcivia A, Bouillot JL, Dietrich A, Klöting $\mathrm{N}$, et al. Adipocyte size threshold matters: link with risk of type 2 diabetes and improved insulin resistance after gastric bypass. J Clin Endocrinol Metab. 2014; 99(8):E1466-70.

33. Skurk T, Alberti-Huber C, Herder C, Hauner H. Relationship between adipocyte size and adipokine expression and secretion. J Clin Endocrinol Metab. 2007;92(3):1023-33.

34. Hernanz R, Briones AM, Salaices M, Alonso MJ. New roles for old pathways? A circuitous relationship between reactive oxygen species and cyclo-oxygenase in hypertension. Clin Sci (Lond). 2014;126(2):111-21.

35. Ward NC, Hodgson JM, Puddey IB, Mori TA, Beilin LJ, Croft KD. Oxidative stress in human hypertension: association with antihypertensive treatment, gender, nutrition, and lifestyle. Free Radic Biol Med. 2004;36(2):226-32.

36. Tangvarasittichai S. Oxidative stress, insulin resistance, dyslipidemia and type 2 diabetes mellitus. World J Diabetes. 2015;6(3):456-80. 
Corresponding author: S. Panda, Associate Professor, Department of Biochemistry, PRM Medical College, Baripada, Odisha, India. E-mail: dr.suchismitapanda17@gmail.com

S. Panda ORCID: 0000-0003-0034-1369

Dash Manoj K. ORCID:0000-0001-6771-126X

Thatoi Pravat K. ORCID:0000-0003-4407-5533

Dandapat J. ORCID:0000-0003-0928-1585

Rath B. ORCID:0000—0002-5232-4993

Ответственный за переписку: Панда С., доцент кафедры биохимии медицинского колледжа РRM, Барипада, Одиша, Индия. E-mail: dr.suchismitapanda17@gmail.com

Панда C. ORCID: 0000-0003-0034-1369

Манодж Даш K. ORCID: 0000-0001-6771-126X

Прават Татой K. ORCID: 0000-0003-4407-5533

Дандапат Дж. ORCID: 0000-0003-0928-1585

Рат Б. ORCID: 0000—0002—5232—4993 